\title{
Antioxidant, antibacterial and antiviral properties of Goniothalamus umbrosus leaves methanolic extract
}

\author{
Noor-Zarina Abdul-Wahab, Saleha Shahar, Halimah Abdullah-Sani, \\ Azimahtol Hawariah Lope Pihie and Nazlina Ibrahim*
}

\author{
School of Biosciences and Biotechnology, Faculty of Science and Technology, Universiti Kebangsaan Malaysia, \\ Bangi 43600, Selangor. \\ Accepted 15 July, 2011
}

\begin{abstract}
The antioxidant, antibacterial, and antiviral effects of crude methanol extract from the leaves of Goniothalamus umbrosus were studied. Good free radical scavenging activity using 1,1-diphenyl-2picrylhydrazyl (DPPH) assay was shown by the extract at $E_{50}$ of $0.263 \mathrm{mg} / \mathrm{ml} \mathrm{compared} \mathrm{to} 0.01 \mathrm{mg} / \mathrm{ml}$ for trolox as the positive control. The extract showed greater antibacterial activity against Grampositive bacteria than Gram-negative with methicillin resistant Staphylococcus aureus (MRSA) isolates were more sensitive than methicillin sensitive $S$. aureus. Cytotoxicity testing of the leaf extract and goniothalamin a styrylpyrone derivative (SPD) as a lead compound found mostly in the genus Goniothalamus was performed on Vero cells. From the test, the $\mathbf{C C}_{50}$ value for the extract was $125 \mu \mathrm{g} / \mathrm{ml}$ and for SPD $31.25 \mu \mathrm{g} / \mathrm{mL}\left(1.563 \times 10^{-7} \mu \mathrm{M}\right)$. Antiviral test was carried out against Herpes Simplex virus type 1 infected to Vero cells. The results showed that $G$. umbrosus leaf methanol extract was effective in showing the antiviral activity in all three treatments but SPD is effective only in the first treatment; 1) $(\mathrm{C}+\mathrm{V})+\mathrm{E}$, extract and SPD were able to control virus post-infection 2) $(\mathrm{C}+\mathrm{E})+\mathrm{V}$ : the extract has prophylactic activity implied by treatment of cells with the extract for one day before viral infection and 3) $C_{+}\left(V_{+} E\right)$ refers to the ability of extract to control viral infectivity when extract and virus was added simultaneously to cell. This study showed the potential of non-cytotoxic G. umbrosus leaf methanol extract as herbal alternative against MRSA and herpes simplex viruse (HSV) -1 .
\end{abstract}

Key words: Goniothalamus umbrosus, leaf, methanol extract, styrylpyrone derivative, antioxidant, antibacterial, cytotoxicity, antivirus.

\section{INTRODUCTION}

Goniothalamus umbrosus J. Sinclair or locally known as kenerak is widely utilized by locals in Malaysia for postpartum healthcare, general well-being, male libido and for

\footnotetext{
${ }^{*}$ Corresponding author. E-mail: nazlina@ukm.my. Tel: +60389213815. Fax: +60389252698.
}

Abbreviations: CHO, Chinese hamster ovary; MRSA, methicillin resistant Staphylococcus aureus; SPD, styrylpyrone derivative; DPPH, 1,1-diphenyl-2-picrylhydrazyl; HSVs, herpes simplex viruses; MEM, minimal essential medium; NRU, neutral red uptake; E, extract; V, viral; C, cells; MSSA, methicillin sensitive S. aureus; VISA, vancomycin intermediate-resistant Staphylococcus aureus; VRSA, vancomycin resistant Staphylococcus aureus; OD, optical density. abortion (Mat-Salleh and Latiff, 2002). Studies related to G. umbrosus includes the chemical composition (Ahmad and Din, 2002; Abbdewahab et al., 2009; Abdelwahab et al., 2009), antioxidant, antibacterial activity (Abdel-Wahab et al., 2009a,b) and genotoxicity in Chinese hamster ovary (CHO) cell line (Umar-Tsafe et al., 2004). Different Goniothalamus species have the ability to elaborate series of acetogenins and styryl lactones which are cytotoxic against a broad array of cancer cells including breast, colon, kidney and pancreatic carcinoma cells (reviewed in Wiart, 2007; Yang et al., 2000).

The antiviral activity of $G$. umbrosus or in other species of the same genus is not known. The emergence of viral resistant variants after prolonged treatment in immunocompromised patients has been the main reasons for the continuous search of novel anti herpetic agents. It is 
known that the herpes simplex viruses (HSVs) have evolved mechanisms to inhibit host cell death, or apoptosis (Jerome et al., 1998). On the other hand, styryl lactones from Goniothalamus sps have been known to activate apoptosis in mammalian and cancer cells (Inayat-Hussain et al., 1999; Lee et al., 2003).

Thus, in this study we would like to test on a hypothesis that the G. umbrosus leaf extract which may contain styryl lactones has the capability in promoting apoptosis of HSV-1 infected cells resulting in the inhibition of virus replication. In this study, we tested goniothalamin, a styrylpyrone derivative to provide an insight as the potential compound that may exhibit the antivirus property. The objectives of this study include determination of the antioxidant, antibacterial activity towards clinically important bacteria and cytotoxicity to normal cells of crude methanol extract from $G$. umbrosus leaves.

\section{MATERIALS AND METHODS}

\section{Plant collection and what}

The plant collected near Sungai Kelantan, Kelantan, Malaysia was identified by Kamarudin Mat-Salleh with a voucher specimen deposited in the UKM Herbarium (Voucher No: NZS 3148). Airdried G. umbrosus leaves $(200 \mathrm{~g})$ were finely powdered before extracted with methanol using a Soxhlet apparatus. The crude methanol extract were concentrated with a rotary evaporator (Laborata 4000, Heidolph, Schwabach, Germany) and dried. Goniothalamin or SPD from $G$. umbrosus prepared by the method of Jewers et al. (1972) was tested in the cytotoxicity and antiviral study.

\section{Free radical scavenging activity of DPPH}

The assay was used to measure the free radical scavenging capacity of the methanol extract according to Mothana et al. (2008). Various concentrations of the extract at $500 \mu \mathrm{l}$ were added to $500 \mu \mathrm{l}$ of $0.1 \mathrm{mM}$ 2,2-Diphenyl-1-picrylhydrazyl (DPPH) (Sigma-Aldrich, country) in methanol solution. After $30 \mathrm{~min}$ incubation at $25^{\circ} \mathrm{C}$, the absorbance was measured at $\lambda=517 \mathrm{~nm}$ using a Shimadzu 1601 UV/Vis spectrophotometer. Percentage of free radical scavenging activity was calculated using the equation: $\left(\mathrm{Abs}_{\text {control }}-\mathrm{Abs}_{\text {sample }}\right)$ / $\mathrm{Abs}_{\text {control }} \mathrm{x}$ 100. Antioxidant activity was expressed as $\mathrm{EC}_{50}$ (effective concentration in $\mathrm{mg} / \mathrm{ml}$ of samples or positive controls that reduces the absorbance of $\mathrm{DPPH}$ by $50 \%$ compared to the negative control) which was estimated from dose-response curves. Synthetic antioxidant reagent 6-Hydroxy-2,5,7,8tetramethylchroman-2-carboxylic acid (trolox) (Sigma-Aldrich, country) was used as the positive control and all tests were carried out in triplicate.

\section{Antibacterial test}

Assay was done by disc diffusion method (Bauer et al., 1966) on Mueller Hinton agar plates plated with test organisms listed in Table 1. Bacteria were obtained from the stock culture collection Microbiology Laboratory, School of Biosciences and Biotechnology, Universiti Kebangsaan Malaysia. Sterile filter paper disks $(6 \mathrm{~mm}$ diameter) soaked with $50 \mu \mathrm{l}$ of extract with concentrations of 100 ,
$50,25,10$ or $5 \mathrm{mg} / \mathrm{ml}$ and placed onto the plated agar. Streptomycin $(10 \mu \mathrm{g} / \mathrm{disc})$ were used as a positive standard against Gram negative bacteria, Penicillin (10 $\mu \mathrm{g} / \mathrm{disc})$ for Gram positive bacteria and vancomycin (10 $\mu \mathrm{g} /$ disc) for methicillin resistant Staphylococcus aureus (MRSA). Negative control was performed using paper discs loaded with $50 \mu \mathrm{l}$ of methanol. The plates were incubated at $37^{\circ} \mathrm{C}$ for $24 \mathrm{~h}$ after which zones of inhibition were measured. The experiment was carried out in duplicate.

\section{Cytotoxicity test}

The methanol extract $(1 \mathrm{mg})$ was first reconstituted in $50 \mu \mathrm{l}$ methanol and then further diluted with $950 \mu \mathrm{l}$ minimal essential medium (MEM) with $5 \%$ fetal bovine serum (GIBCO)-MEM/FCS to obtain a $1 \mathrm{mg} / \mathrm{ml}$ stock solution. Confluent Vero cells (African green monkey kidney cells) grown in 96-well microtitre plate were treated with the extract that was diluted to $1,0.5,0.25,0.125,0.0625$, $0.0313,0.016$ and $0.008 \mathrm{mg} / \mathrm{ml}$ for $48 \mathrm{~h}$ incubation. We included SPD for initial screening of cytotoxicity and antiviral activity in this study.

Cytotoxic activity was determined by the protocol for neutral red uptake (NRU) assay (Fotakis and Timbrell, 2005). Absorbance of released dye was recorded by using microplate reader (Labsystems Multiscan Multisoft) at $\lambda=550 \mathrm{~nm}$. Readout from each well was normalized against the absorbance from empty wells and data was presented as the percentage of survived cells compared to control cells. The $50 \%$ cytotoxic concentration $\left(\mathrm{CC}_{50}\right)$ value was determined.

\section{Antiviral assay}

The viral dose that kills cell $50 \%$ of cell population $\left(\mathrm{TCID}_{50}\right)$ was first determined using the NRU assay (Danve et al., 2002). Screening for antiviral activity was performed using 3 different treatments according to Nurul-Aini et al. (2006); 1) To evaluate the effect of extract $(E)$ after viral $(V)$ adsorption, cells $(C)$ were inoculated with virus for two hours after which the extract/SPD were added or simply $(\mathrm{C}+\mathrm{V})+\mathrm{E}$; 2) To evaluate the effect of compounds on cells before virus inoculation, cells were treated for one day with extract before virus was added, $(\mathrm{C}+\mathrm{E})+\mathrm{V}$ and 3$)$ to evaluate the ability of extract to control viral infectivity thus effecting viral replication cycle; the virus and extract were inoculated at the same time to cells, $\mathrm{C}+(\mathrm{V}+\mathrm{E})$ and incubated for 48 hours. For the antiviral tests, the extracts were diluted to $1.0 \mathrm{CC}_{50}, 0.5 \mathrm{CC}_{50}$ and $0.25 \mathrm{CC}_{50}$ with SPD at $0 \mathrm{CC}_{50}(31.25 \mu \mathrm{g} / \mathrm{ml})$ and $0.5 \mathrm{CC}_{50}(15.63 \mu \mathrm{g} / \mathrm{ml})$.

The viral concentration used for cell inoculations was fixed at 10TCID . Commercial antiviral drug Acyclovir (Sigma-Aldrich) was used as a positive control. Optical density (OD) was related directly to the percentage of viable cells that was inversely proportional to the CPE. The viral replication was measured by the difference between the OD of the cell control and the OD of the virus control OD: viral replication $=[1-O D$ virus control] $-[1-O D$ cell control]. The viral replication was then evaluated in presence of $\mathrm{E}$ : viral replication $E=[1-O D$ (virus $+E)]-[1-O D$ cell control]. The percentage of reduction of the viral replication in the presence of $\mathrm{E}$ was calculated by the formula: Percentage of reduction $(\%$ of reduction $)=[1-($ viral replication E/viral replication $)] \times 100$. When the percentage of reduction of the viral replication was found to be below $10 \%$ the extract was considered as not having antiviral activity (-). When the percentage of reduction of the viral replication was above $50 \%$ in duplicates, the extract was scored as having antiviral activity $(+)$. With a percentage of reduction of the viral replication between 10 and $50 \%$, the extract was classified undetermined antiviral activity $( \pm)$. 
Table 1. Antibacterial activity of methanol extract of G. umbrosus leaves in Gram-positive and Gram-negative bacteria. Note: Average zone of inhibition (in mm) of duplicate including the diameter of the filter paper disc $(6 \mathrm{~mm}) . \mathrm{S}=\operatorname{streptomycin}(10 \mu \mathrm{g} / \mathrm{disc}) \mathrm{P}=\mathrm{penicillin}(10 \mu \mathrm{g} / \mathrm{disc})$ $\mathrm{V}=$ vancomycin $(10 \mu \mathrm{g} / \mathrm{disc})$. NT= not tested.

\begin{tabular}{|c|c|c|c|c|c|c|c|c|}
\hline \multirow{2}{*}{$\begin{array}{l}\text { Test organism } \\
\text { Gram-positive bacteria }\end{array}$} & \multicolumn{5}{|c|}{ Extract concentration $(\mathrm{mg} / \mathrm{ml})$} & \multicolumn{3}{|c|}{ Antibiotic control } \\
\hline & 100 & 50 & 25 & 10 & 5 & $\mathbf{S}$ & $\mathbf{P}$ & $\mathbf{V}$ \\
\hline Staphylococcus aureus ATCC 11632 & 9 & 8 & 8 & 7 & 8 & NT & 25.0 & NT \\
\hline Streptococcus epidermidis ATCC 12228 & 8 & 8 & 6 & 6 & 9 & NT & 20.0 & NT \\
\hline Bacillus thuringiensis ATCC 10792 & 8 & 6 & 6 & 6 & 6 & NT & 12.0 & NT \\
\hline MRSA 11 (Clinical isolate) & 12 & 10 & 8 & 9 & 9 & NT & NT & 20.0 \\
\hline MRSA 12 (Clinical isolate) & 9 & 8 & 7 & 6 & 6 & NT & NT & 20.0 \\
\hline MRSA 13 (Clinical isolate) & 18 & 8 & 9 & 11 & 6 & NT & NT & 21.0 \\
\hline MRSA 14 (Clinical isolate) & 20 & 9 & 7 & 6 & 6 & NT & NT & 20.0 \\
\hline MRSA 15 (Clinical isolate) & 11 & 10 & 9 & 6 & 6 & NT & NT & 17.0 \\
\hline MRSA 17 (Clinical isolate) & 8 & 6 & 6 & 6 & 6 & 6 & 6 & 16 \\
\hline \multicolumn{9}{|l|}{ Gram-negative bacteria } \\
\hline Pseudomonas aeruginosa ATCC 10145 & 13 & 10 & 9 & 8 & 8 & 19 & NT & NT \\
\hline Vibrio cholera & 10 & 9 & 8 & 6 & 6 & 14 & NT & NT \\
\hline Vibrio parahaemolyticus ATCC 17802 & 9 & 8 & 7 & 6 & 6 & 11 & NT & NT \\
\hline Salmonella typhi & 8 & 9 & 7 & 9 & 9 & 9 & NT & NT \\
\hline Salmonella dysentriae & 10 & 6 & 6 & 6 & 6 & 26 & NT & NT \\
\hline Serratia marcescens ATCC 13880 & 8 & 8 & 6 & 6 & 6 & 12 & NT & NT \\
\hline
\end{tabular}

Table 2. The free radical scavenging activity percentage and $50 \%$ effective concentration $\left(E_{50}\right)$ of crude methanol extract of $G$. umbrosus leaves and trolox as control.

\begin{tabular}{lcccccccc}
\hline & \multicolumn{7}{c}{ Free radical scavenging activity (\%) } & \multirow{2}{*}{ EC50 } \\
\cline { 2 - 8 } Test sample & \multicolumn{8}{c}{ Concentration $(\mathbf{m g} / \mathbf{m l})$} \\
\cline { 2 - 8 } & $\mathbf{0 . 0 0 5}$ & $\mathbf{0 . 0 2 5}$ & $\mathbf{0 . 0 5}$ & $\mathbf{0 . 1 9 5}$ & $\mathbf{0 . 3 9 1}$ & $\mathbf{0 . 7 8 1}$ & $\mathbf{1 . 5 6 3}$ & \\
\hline G. umbrosus & - & - & - & 26 & 65 & 75 & 84 & 0.263 \\
Trolox & 39 & 86 & 88 & 91 & 92 & 91 & 93 & 0.01 \\
\hline
\end{tabular}

\section{RESULT AND DISCUSSION}

\section{Antioxidant activity}

The free radical scavenging effect of crude methanol extract of $G$. umbrosus leaves and trolox with their $\mathrm{EC}_{50}$ values are shown in Table 2 . The extract showed maximum inhibition of about $84 \%$ and promising antioxidant activity with an $E_{50}$ of $0.263 \mathrm{mg} / \mathrm{ml}$ Since $E_{50}$ is a measure of inhibitory concentration, a lower $E_{50}$ value would reflect greater antioxidant activity of the sample (Yamaguchi et al., 1998).

Abdel-Wahab et al. (2009a) reported that the dichloromethane extract of $G$. umbrosus leaf has low antioxidant activity due to lack of phenolic content. However, a study on the antioxidant activity of $G$. macrophyllus root methanol extract showed $I C_{50}$ value of $0.96 \mathrm{mg} / \mathrm{ml}$ (Batubara et al., 2010). The antioxidant activity in plants has always been investigated for their capacity to scavenge free radicals. However, in
Annonaceous plant species this activity have not been reported widely even though anticancer agents like acetogenins and phenolic compounds styryl-lactones which are cytotoxic against a broad range of cancer types (Wiart, 2007; McLaughlin, 2008) are available. The anticancer activity has not been associated with the direct antioxidant activity but to the inhibition of superoxide dismutase activity in malignant cells that leads to free radical mediated damage to mitochondrial membranes, release of cytochrome $\mathrm{c}$, and entry of cells into apoptosis (Huang et al., 2000). The antioxidant activity of phenolics have always been associated with their redox properties, which allow them to act as reducing agents, hydrogen donators, singlet oxygen quenchers and a metal chelation potential (Rice-Evans et al., 1995).

\section{Antibacterial activity}

The zone of inhibition of the crude methanol extract of 
G. umbrosus leaves against test bacteria is shown in Table 1. Broad spectrum antibacterial activity was exhibited by the methanol extract against both Grampositive and Gram-negative bacteria. What is more interesting from this study is that MRSA isolates were more sensitive towards the test substance compared to the non-MRSA or termed Methicillin sensitive $S$. aureus (MSSA). S. aureus may occur as a commensal on skin and in the nose frequently (Whitt and Salyers, 2002) and throat less commonly. The selective activity of the test substance towards more virulent organism such as MRSA shown in this study is very interesting and should be looked into more closely for the specific target or selectivity and mechanism of action.

The results from this study is very important for the development of novel antibiotic for new evolutions of the MRSA bacterium that have been dubbed Vancomycin intermediate-resistant Staphylococcus aureus (VISA) and Vancomycin Resistant Staphylococcus aureus (VRSA) (Schito, 2006).

The antibacterial activity in this study is consistent with the findings of Abdelwahab et al. (2009) that demonstrated a broad spectrum of antibacterial activity against both Gram positive and Gram negative organisms at different extent. The methanol extract used in their study however was extracted first in dichloromethane which most probably causing lipophilic secondary metabolites such as acetogenins and styryl-lactones to be removed. This study however is in agreement with the study reported by Wiart (2007) that showed methanol extract of G. scortechinii inhibited the growth of several nosocomial bacteria with higher antibacterial activity against Grampositive bacteria than Gram-negative bacteria. He hypothesized a new antibacterial pathway that would encompass a 'bacterial apoptosis' due to the fact that mitochondria in eukaryotic cells take their origin in probacterial ancestors from which they inherited NADH:ubiquinone oxidoreductase (Gabaldon et al., 2005).

MRSA strains were different from MSSA mainly due to the ability to the production of different penicillin-binding protein, PBP2A or PBP2', which allows the synthesis of the peptidoglycan layer and cell wall synthesis in the presence of $\beta$-lactams (Appelbaum, 2007). Another important virulence factor associated overall in $77 \%$ of MRSA strains is the Panton-Valentine leukocidin (PVL) (Stevens et al., 2007) which at lower concentrations induces the apoptosis of leukocytes (Genestier et al., 2005), Further studies should be done to determine if any of these factors becomes the target of antibacterial property from the methanol extract of. G. umbrosus leaves.

\section{Cytotoxicity of G. umbrosus leaf methanol extract and SPD}

The $\mathrm{CC}_{50}$ value of leaves crude methanol extract of $G$. umbrosus was $125 \mu \mathrm{g} / \mathrm{ml}$ and SPD was $31.25 \mu \mathrm{g} / \mathrm{mL}$ $\left(1.563 \times 10^{-7} \mu \mathrm{M}\right)$. These values can be considered as low in cytotoxicity as suggested by Shier (1991). Compounds which demonstrated the $\mathrm{CC}_{50}$ value of more than 10-25 $\mu \mathrm{g} / \mathrm{mL}$ can be considered as weak cytotoxicity while compounds with the $\mathrm{CC}_{50}$ value of less than $5.0 \mu \mathrm{g} / \mathrm{ml}$ were considered very active. Thus the crude methanol extract and SPD can be further evaluated for development as antibacterial and antiviral drugs.

Evidence on goniothalamin showed its principal advantage in showing great cytotoxic activity against colon and breast cancer cells and less toxic against normal cells (Wattanapiromsakul et al., 2005). In this study we chose the neutral red assay which is based on the accumulation of the neutral red dye in the lysosomes of viable and uninjured cells (Fotakis and Timbrell, 2005) over the MTT assay which is mainly based on the enzymatic conversion of MTT in the mitochondria. This is to avoid contradicting results that might rise from the direct mitochondrial activities of acetogenins and styryl-lactones such as goniothalamin which might be available in the extract.

\section{Antiviral activity}

In the antiviral study, the extract showed the ability to reduce viral replication by all means of treatment (Table $3)$. There is an agreement in the activities shown by the extract and SPD in treatment $(\mathrm{C}+\mathrm{V})+\mathrm{E}$ but not in others. The result demonstrated that the extract and SPD were capable to control viral infection after $2 \mathrm{~h}$ post-infection which according to Honess and Roizman (1974) is the early stage of replication particularly during viral attachment. This implies that both $G$. umbrosus leaf methanol extract and SPD were effective in controlling virus postinfection

Cells that were treated for one day with the extract before virus was added, $(\mathrm{C}+\mathrm{E})+\mathrm{V}$ at $1 \mathrm{CC}_{50}$ and $0.5 \mathrm{CC}_{50}$ showed control to viral replication implying the ability to act as a prophylactic substance against viral infection (Table 3). The extract was also effective in protecting cells against viral infection when added together to cells in $\mathrm{C}+(\mathrm{V}+\mathrm{E})$. This refers to the ability of extract to control viral infectivity during the early replication phase. In this study, acylclovir which is a nucleoside analogue showed the ability to protect cell from viral infection in treatment $(\mathrm{C}+\mathrm{E})+\mathrm{V}$ and when added simultaneously with virus to cell, $\mathrm{C}+(\mathrm{V}+\mathrm{E})$. The methanol extract have not been purified and may contain more than one antiviral compound that could inhibit the replication of HSV by different mechanism. This explains the data showing that the methanol extract has antiviral activity in all the treatments compared to SPD which is only effective in post-infection treatment. Further purification of the extract will allow the determination of compounds able to inhibit HSV replication.

Herpesviruses possess $\mathrm{Bcl}-2$ homologues that block 
Table 3. The antiviral effect of crude methanol extract of $G$. umbrosus leaves, goniothalamin and acylclovir (E) in different treatments.

\begin{tabular}{|c|c|c|c|c|c|}
\hline Test substance & $\begin{array}{c}\mathbf{C C}_{50} \\
\text { equivalent }\end{array}$ & $\begin{array}{c}\text { Concentration } \\
(\mu \mathrm{g} / \mathrm{ml})\end{array}$ & $(C+V)+E$ & $(C+E)+V$ & $C+(V+E)$ \\
\hline \multirow[t]{3}{*}{ G. umbrosus } & 2 & 250 & + & \pm & + \\
\hline & 1 & 125 & + & + & + \\
\hline & 0.5 & 63 & + & + & + \\
\hline \multirow[t]{2}{*}{ Goniothalamin } & 1 & 31.25 & + & \pm & - \\
\hline & 0.5 & 15.63 & + & - & - \\
\hline Acyclovir & & 125 & & & \\
\hline
\end{tabular}

Note: The antiviral activity of the extract or goniothalamin $(E)$ was evaluated based on the percentage of reduction in the viral replication (\% of reduction). Degree of antiviral activity: - = no antiviral activity (\% of reduction is below $10 \%$ ); $+=$ having antiviral activity ( $\%$ of reduction was above $50 \%$ in duplicates); $( \pm$ ) = undetermined (\% of reduction between 10 and $50 \%$ ). Acyclovir as positive control.

apoptosis at the mitochondria before activation of the caspases (Cheng et al., 1997; Marshall et al., 1999; Nava et al., 1997). Restoring the ability of an infected cell to progress through apoptosis is an attractive means of treating viral infections. On the other hand, the apoptosisinducing effect of styryl-lactones from $G$. cheliensis, on human promyelocytic leukemia $\mathrm{HL}-60$ showed the activation of caspase- 3 , reduced the expression of the anti-apoptotic gene $\mathrm{Bcl}-2$, and increased the expression of the pro-apoptotic gene Box via cAMP dependent protein kinase mechanism (Wang et al., 2005). Thus, further studies on understanding the mechanism of action for methanol extract of $G$. umbrosus leaves and SPD in inducing apoptosis in virus infected cells is currently being undertaken.

\section{Conclusion}

This study demonstrates the ability of methanol extract of G. umbrosus leaves as an antioxidant with broad spectrum antibacterial activity and pronounced activity towards MRSA. The extract and SPD were active in inhibiting viral replication after virus was infected to cells. The extract was effective as a prophylaxis and when available during virus infection.

\section{ACKNOWLEDGEMENTS}

We wish to thank Ministry of Higher Education (UKM-ST01-FRGS0051-2006 and UKM-OUP-KPB-31-156/2011) and International Foundation for Science (IFS F/4198-1, STGL-005-2007) for their financial supports in this project.

\section{REFERENCES}

Abbdewahab SI, Ain NM, Abdul AB, Taha MME,Tengku-lbrahim TA (2009). Energy-dispersive X-ray microanalysis of elements' content and antimicrobial properties of Pereskia bleo and Goniothalamus umbrosus. Afr. J. Biotech., 8(10): 2375-2378.

Abdelwahab SI, Abdul AB, Elhassan MM, Mohan S, Ibrahim MY, Mariod AA, AlHaj NA, Abdullah R (2009). GC/MS determination of bioactive components and antibacterial properties of Goniothalamus umbrosus extracts. Afr. J. Biotech., 8(14): 3336-3340.

Abdel-Wahab SI, Abdul AB, Fong HK, Mohan S, Elhassan MM, AlZubairi AS, Mariod AA (2009a). Antimicrobial and free radical scavenging activities of the dichloromethane extract of Goniothalamus umbrosus. Int. J. Trop. Med., 4(1): 32-36.

Abdel-Wahab SI, Abdul AB, Mohan S, Al-Zubairi AS, Elhassan MM, AIZubairi AS (2009b). Oncolysis of breast, liver and leukemia cancer cells using ethyl acetate and methanol extracts of Goniothalamus umbrosus. Res. J. Biol. Sci., 4(2): 209-215.

Ahmad FB, Din LB (2002). Isolation and characterization of dehydrogoniothalamin (I) from Goniothalamus umbrosus. Nat. Prod., 33(45):199.

Appelbaum PC (2007). Microbiology of antibiotic resistance in Staphylococcus aureus. Clin. Infect. Dis., 45: S165-S170.

Batubara I, Darusman LK, Mitsunaga T, Rahminiwati M, Djauhari E (2010). Potency of Indonesian medicinal plants as tyrosinase inhibitor and antioxidant agent. J. Biol. Sci., 10(2): 138-144.

Bauer AW, Kirby WMM, Sherries JC, Turck M (1966). Antibiotic susceptibility testing by standard single disc diffusion method. Am. J. Clin. Path., 45:426-33.

Cheng EH, Nicholas J, Bellows DS, Hayward GS, Guo HG, Reitz MS, Hardwick JM (1997). A Bcl-2 homolog encoded by Kaposi sarcomaassociated virus, human herpesvirus 8 , inhibits apoptosis but does not heterodimerize with Bax or Bak. Proc. Natl. Acad. Sci., 94(2): $690-694$

Danve C, Morfin F, Thouvenot D, Aymard M (2002). A screening dyeuptake assay to evaluate in vitro susceptibility of herpes simplex virus isolates to acyclovir. J. Virol. Methods, 105: 207-217.

Fotakis N, Timbrell M (2005). In vitro cytotoxicity assays: Comparison of $\mathrm{LDH}$, neutral red, MTT and protein assay in hepatoma cell lines following exposure to cadmium chloride. Toxicol. Lett., 160: 171-177.

Gabaldon T, Rainey D, Huynen MA (2005). Tracing the evolution of a large protein complex in the eukaryotes, NADH: ubiquinone oxidoreductase (Complex I). J. Mol. Biol., 348:857-70.

Genestier AL, Michallet MC, Prevost G, Bellot G, Chalabreysse L, Peyrol S, Thivolet F, Etienne J, Lina G, Vallette FM, Vandenesch F, Genestier L (2005). Staphylococcus aureus Panton-Valentine leukocidin directly targets mitochondria and induces Bax-independent apoptosis of human neutrophils. J. Clin. Invest., 115:3117-3127.

Honess RW, Roizman B (1974). Regulation of herpes macromolecular synthesis. Cascade regulation of the synthesis of three groups of viral proteins. J. Virol., 14: 8-19.

Huang P, Feng L, Oldham EA, Keating MJ, Plunkett W (2000). Superoxide dismutase as a target for the selective killing of cancer cells. Nature, 407: 390-395.

Inayat-Hussain SH, Osman A, Din LB, Ali AM, Snowden RT, 
MacFarlane M, Cain K (1999). Caspases-3 and -7 are activated in SPDinduced apoptosis in human Jurkat T-cells. FEBS Lett., 456: 379-383.

Jerome KR, Tait JF, Koell DM, Corey L (1998). Herpes simplex virus type 1 renders infected cells resistant to cytotoxic T-lymphocyteinduced apoptosis. J. Virol., 72:436-44

Jewers KJ, Dougnan B, Manchanda AH, Blunden G, Kyi A, Wetchapinan S (1972). Goniothalamin and its distribution in four Goniothalamus spp. Phytochemistry, 11: 2025-2030.

Lee ATC, Azimahtol HLP, Tan AN (2003). Styrylpyrone derivative (SPD) induces apoptosis in a caspase-7-dependent manner in the human breast cancer cell line MCF-7. Cancer Cell Int., 3: 16.

Marshall WL, Yim C, Gustafson E, Graf T, Sage DR, Hanify K, Williams L, Fingeroth J, Finberg RW, (1999). Epstein- Barr virus encodes a novel homolog of the $\mathrm{bcl}-2$ oncogene that inhibits apoptosis and associates with Bax and Bak. J. Virol., 73(6): 5181-5185.

Mat-Salleh K, Latiff A (2002). Malaysian Medicinal Plants (In Malay). Universiti Kebangsaan Malaysia. pp. 797.

McLaughlin JL (2008). Paw Paw and cancer: Annonaceous acetogenins from discovery to commercial products. J. Nat. Prod., 71: 1311-1321.

Mothana RAA, Abdo SAA, Hasson S, Althawab FMN, Alaghbari SAZ, Lindequist $U$ (2008). Antimicrobial, antioxidant and cytotoxic activities and phytochemical screening of some Yemeni medicinal plants. Evid. Based Comp. Alternat. Med., 7(3): 323-330.

Batubara MA, Jantan I, Ahmad F, Jalil J (2010). Antiplatelet aggregation and platelet activating factor (PAF) receptor antagonistic activities of the essential oils of five Goniothalamus species. Molecules, 15(8): 5124-5138.

Nava VE, Cheng EH, Veliuona M, Clem RJ, Mayer ML, Hardwick JM (1997). Herpesvirus saimiri encodes a functional homolog of the human bcl-2 oncogene. J. Virol., 71(5): 4118-4122.

Nurul-Aini MN, Said MI, Nazlina I, Hanina MN, Ahmad IB (2006). Screening for antiviral activity of sweet lemon grass (Cymbopogon nardus (L.) Rendle) fractions. J. Biol. Sci., 6(3): 507-510.

Rice-Evans CA, Miller NJ, Bolwell PG, Bramley PM, Pridham JB (1995). The relative antioxidant activities of plant-derived polyphenolic flavonoids. Free. Radical. Res., 23: 375-383.
Schito GC (2006). The importance of the development of antibiotic resistance in Staphylococcus aureus. Clin. Microbiol. Infect., 12 (Suppl. 1): 3-8.

Shier WT (1991). Mammalian cell culture on $\$ 5$ a day: A lab manual of low cost methods. Nat. Inst. of Biotech and Appl. Micro. (BIOTECH), pp 64-71. Philipines: Laguna.

Stevens DL, Ma Y, Salmi DB, Mclndoo E, Wallace RJ, Bryant AE (2007). Impact of antibiotics on expression of virulence-associated exotoxin genes in methicillin-sensitive and methicillin-resistant Staphylococcus aureus. J. Infect Dis., 195: 202-211.

Umar-Tsafe N, Mohamed-Said MS, Rosli R, Din BD, Lai LC (2004). Genotoxicity of goniothalamin in $\mathrm{CHO}$ cell line. Mutat. Res., 562: 91102.

Wang G, Ahmad KA, Ahmed K (2005). Modulation of death receptor mediated apoptosis by CK2. Mol. Cell Biochem., 274: 201-5.

Wattanapiromsakul C, Wangsintaweekul B, Sangprapan P, Itharat A, Keawpradub N (2005). Goniothalamin, a cytotoxic compound, isolated from Goniothalamus macrophyllus (Blume) Hook. f. \& Thomson var. macrophyllus. Songklanakarin J. Sci. Technol., 27(2): 479-487.

Whitt DD, Salyers AA (2002). "14". Bacterial Pathogenesis: A Molecular Approach (2nd ed.). USA: ASM Press.

Wiart C (2007). Goniothalamus species: A source of drugs for the treatment of cancer and bacterial infection? Evid. Based Comp. Alternat. Med., 4(3): 299-311.

Yamaguchi T, Takamura H, Matoba T, Terao J (1998). HPLC method for evaluation of the free radical-scavenging activity of foods by using 1,1-diphenyl-2-picrylhydrazyl. Biosci. Biotechnol. Biochem., 62(6): $1201-1204$.

Yang S, Yu J, Xu L (2000). Chemical constituents of Annonaceae plants and their antitumour activities. Zhongguo Yi Xue Ke XueYuan Xue Bao, 22: 376-82 